\title{
Epo, by any other name
}

\author{
Regulators must be given ways to approve follow-on 'biosimilars' when proteins fall out of patent if the \\ fruits of molecular biology are to have the greatest possible effect on health care.
}

$$
\text { L }
$$

ate last month, the European Commission granted marketing authorizations to three companies for generic versions, or 'biosimilars', of the hormone erythropoietin. Amgen, the world's largest biotechnology company by sales, started selling Epogen ('Epo'), its recombinant version of this naturally occurring hormone, in 1989, producing it from cells into which the relevant gene had been engineered. The drug's ability to boost red blood-cell production has led to its widespread use to treat the anaemia associated with some diseases. Epogen and its newer incarnation, Aranesp, earned nearly US $\$ 7$ billion for Amgen last year, and more than $\$ 3$ billion for Johnson \& Johnson, which has licensed the drug from Amgen and markets it in the United States, Europe and elsewhere. Now that the commission has allowed other companies to market their own version, revenues from Johnson \& Johnson's estimated 250,000 European customers look set to erode. Sandoz, the generic-drugs branch of Novartis, said on 10 September that it will have its version of the drug on the market in the United Kingdom and Germany as soon as October, and that it will cost 25-30\% less than Johnson \& Johnson is charging.

The approvals bring to five the number of follow-on biological drugs to which the commission has given the go-ahead since it opened up a regulatory path for their approval last year. Eleven more applications are in a lengthening queue at the European Agency for the Evaluation of Medicinal Products. In the United States, though, the situation is very different. When the US patents on Epo expire, Amgen will not, as things stand now, face any new competition. The US Food and Drug Administration (FDA) doesn't have the authority to designate subsequent versions of biologicals - drugs consisting of proteins made using biotechnology — as interchangeable with currently marketed products. The potential for such products is large (see News Feature, page 274); sales of biological drugs no longer protected by patents in the United States were worth $\$ 11.5$ billion in 2006. But at the moment the United States does not have an abbreviated regulatory system for biosimilars, which seek simply to mimic the drugs already on sale, so - with rare exceptions - there is no way into that market.

This year Congress vowed to put this matter right. A bill drafted by leading liberal Democrats and conservative Republicans in the Senate and backed by the Senate health committee would give biotech companies twelve years of market exclusivity on any new biological drug from the time that it is approved. This is longer than they might get from patent protection alone, which starts to run out as soon as the patent is granted even if the drug has not been approved. Companies with an interest in making biosimilars would, for their part, receive an abbreviated pathway to FDA approval of their follow-on products once that twelve-year period is up.

But neither the generics industry nor the biotech industry seem to be pushing to have this compromise passed by the House. Why? Because, compromise that it is, neither side is entirely happy. The generics industry

"Congress should make it happen now." is assuming that it will get a better deal in 2009, under a new US president. The biotech industry, although willing to stomach the compromise, is not going to go to bat for it. And so American health-care providers will continue to pay exorbitant prices for drugs such as Genentech's Cerezyme (imiglucerase) for Gaucher's disease, which is off patent but still costs up to $\$ 200,000$ per patient per year. The US biotech industry will continue to operate under a cloud of uncertainty that does not hamper its European competitors.

No one is suggesting that biosimilars will ever be marketed with the large discounts - $70 \%$ or more - that consumers enjoy when they buy generic versions of small-molecule drugs. But given current prices, regulation that facilitates generic competition on pricey biologicals while duly protecting innovators would still help health-care providers greatly. It's fair, it's possible, and Congress should make it happen now.

\section{Regulatory failures}

\section{Outbreaks of foot-and-mouth disease have revealed unacceptable shortcomings in UK regulation.}

$\mathrm{N}$ othing gets a British prime minister to the emergencyresponse table quicker than a security threat, and biosecurity is no exception. Gordon Brown has already found himself having to respond promptly to outbreaks of foot-and-mouth disease, as did his predecessor Tony Blair. Unless the proper lessons are learned from these outbreaks, he could face more, and more serious, such emergencies in the future.

An outbreak in 2001 led to widespread culls of British livestock and devastating financial losses to farmers and the economy. Two more outbreaks this year, in which the virus escaped from a research site in Surrey, have been much more contained. Reports by the Health and Safety Executive and by a group of scientists led by Brian Spratt, a bacteriologist from Imperial College London, revealed that the site, in Pirbright, had critical problems with its effluent systems. The government has responded to the report, and set up more reviews to correct regulatory shortcomings.

These shortcomings are glaring enough. The site has two occupants, the publicly funded Institute for Animal Health (IAH) and Merial, a company that produces vaccines against foot-and-mouth disease. The reports conclude that Merial had not breached the terms of its biosecurity licence, awarded by the Department for Environment, Food and Rural Affairs (DEFRA). But they acknowledge that 
even though the firm had used chemical treatments to clean up 12,000 litres of fluid containing an estimated $10^{14}$ infectious units of virus in its category 4 containment facility, there was every possibility that the outbreak was caused by effluent from the facility. That such a possibility could meet the terms of a licence beggars belief. DEFRA's licensing standards are in urgent need of review; the government response rightly, if belatedly, acknowledges that the company probably needs to install sterilizing heat treatment.

Another belated government response is its recognition of two glaring conflicts of interest that bedevil biosecurity at the site: that the person responsible for Merial's biosecurity was also its site director; and that the site's other occupant, the IAH, is not only licensed by DEFRA but is also in large part funded by it. Such financially conflicted dual responsibilities are a recipe for underspending on security.

But there is no public sign, either from the government or elsewhere, of a more fundamental concern. The IAH is central to Britain's ability to protect itself against future outbreaks of animal disease, whether unleashed by natural causes, human error or enemy action. It also has a vital role in these issues internationally. To fulfil these roles the institute requires (and indeed has) a world-class research base that lets it address key scientific questions and at the same time maintain and develop the techniques needed to identify and deal with diseases. It also requires infrastructure to support both research and surveillance. Spratt's committee mentions chronic shortcomings in lab conditions at the IAH, although they are not blamed for the outbreak.

Here DEFRA is yet again in the frame. The IAH's core funding is provided by the United Kingdom's Biotechnology and Biological Sciences Research Council (BBSRC). Its surveillance obligations and other practical duties mean that it struggles for funding against other institutes with roles that lie squarely within the BBSRC's research remit. DEFRA is supposedly obliged to uphold a government principle to fully fund the institute's infrastructure costs. This it has failed to do - a failure that has become marked, as it has cut its support for the $\mathrm{IAH}$ at a time when such support seems more important than ever.

The IAH's role was last reviewed in 2002. At that time, the review committee emphasized the need for biological and regulatory research to be strengthened at the IAH, and for its funders to develop a coherent approach.

Recently, the relevant bodies have seen a wave of turnover in their key players - ministers and the chief scientists of both the government at large and DEFRA in particular have changed, as has the head of the BBSRC (which, for good measure, is now supported through a new department). If he wants to minimize the frequency of future emergency committee meetings, Gordon Brown should bang all these new heads together and ensure that the 2002 funding recommendations for the IAH are implemented by all key players, and soon.

\section{Drill often, drill deep}

Splice the mainbrace: the greatest scientific oceandrilling vessel ever built is going to sea.

A fter 18 years, 1,800 boreholes, some 36,000 cores and a host of impressive scientific discoveries, the international Ocean Drilling Program came to a close in 2003. Its successor, the Integrated Ocean Drilling Program (IODP), has hired some ships for drilling expeditions to sites of scientific importance, but has been waiting for a new flagship before going full steam ahead. The wait is now over. This week marks the research debut of the mammoth Japanese research vessel Chikyu (see News Feature, page 278). Japan has spared no expense in providing its riser-protected drilling pipe, its elaborate laboratories, its cushy cabins and all the other amenities a world-travelling scientist at sea might need. There is unlikely to be a research drilling ship in the near, or not-so-near, future to match it.

The ship's future will not be plain sailing, though, unless both Japan and the international community learn from the past. Japan is not the only country to plop down money for a big science project without providing the resources - especially the human resources - to make best use of it. But this it has done, and its government must now cultivate scientists who can use Chikyu to answer big questions in creative and effective ways. Japanese researchers will be competing with the international community for the IODP funding pot, and if they wish to play a leading role aboard Chikyu they must have the type of highcalibre proposals that will win respect in the international arena. This may not be easy: at Japan's sole academic oceanographic institution
- the Ocean Research Institute at Tokyo University - the number of graduate students and postdoctoral fellows has dropped dramatically over the past five years. Japan's science ministry needs to support new faculty positions, new postdoctoral positions, more graduate students and more positions for visiting Earth scientists from abroad.

And as magnificent as it is, Chikyu cannot do everything that the IODP needs done. The programme has two other 'pillars' that have run into problems. The US-led contribution is a vessel meant to complement Chikyu, but this veteran of the Ocean Drilling Program, JOIDES Resolution, continues to languish at a dock in Singapore because of lack of funding and skilled workers to refurbish it. European organizers of the third pillar - mission-specific platforms - must cope with the fact that the oil industry's appetite for ships and staff leaves little capacity for equipment and staffing for scientific expeditions. The IODP has struggled just to rent mission-specific platforms for individual cruises, even though member countries have paid their dues and invested the time of their leading scientists.

A downturn in the oil price after investment in new fields might alleviate those problems by reducing the incentives for exploration (although don't bet on it). Even if it does, though, and especially if it doesn't, IODP managers must do what they can to get JOIDES Resolution refitted and back at sea. It would be a shame if, after all the scientific and diplomatic work that has gone into the exemplary international setting up of the IODP, the efforts ended up wasted by the budgetary stress of an oil crisis that was not predicted when the IODP started its planning. The launch of Chikyu should serve as a wake-up call for scientists, mission planners, and policymakers to redouble their efforts to keep this exciting programme moving in the right direction. Onwards and downwards! 